$\mathrm{DCCA}$ 처리와 저온플라즈마 처리가 양모직물의 염색성에 미치는 영향

정영진

부산대학교, 생명자원과학대학, 바이오소재전공

\title{
Effect of Low Temperature Plasma and DCCA treatment on the Dyeing Properties of Wool Fabric
}

\author{
Young Jin Jung \\ Dept. of Biomaterials Engineering, college of Natural Resource \& Life science, Pusan National University, \\ Miryang, 627-706 Republic of Korea
}

(Received: July 18, 2008/Revised: August 7, 2008/Accepted: August 22, 2008)

\begin{abstract}
For the modification of wool surface, wool fabrics treated with oxygen low-temperature plasma(LTP) and dichloroisocyanuric acid(DCCA) were dyed with milling type acid dye. The difference of dyeing properties on modified and control wool fabric were investigated. DCCA treated wool showed that saturation dye uptake and dyeing desorption ratio were higher than LTP treated wool. Dyeing transition temperatures of DCCA and LTP treated wool fabrics were $20^{\circ} \mathrm{C}$ degree lower than control wool fabric. In light color fastness test, DCCA treated wool fabric was 1 grade lower than LTP or control wool fabric.
\end{abstract}

Keywords: wool, low-temperature plasma, DCCA, saturation dye uptake, dyeing desorption ratio

\section{1. 서 론}

양모섬유는 소수성의 표면 스케일과 친수성의 마이크로피브릴 및 메트릭스로 이루어져 있으므 로 발수성과 흡습성을 동시에 가지고 있어서 한랭 한 환경과 더운 환경에 모두 적용할 수 있다 ${ }^{1,2)}$. 양 모섬유의 크림프(crimp)구조와 시스틴(cystin)가교 는 방적성과 탄력성을 갖게 하는 특유의 품격을 나타내지만 스케일 구조와 탄성은 형태안정성에 매우 불리하게 작용한다. 따라서 양모직물을 형태 안정화 시키는 기능가공은 매우 중요한 가공기술 이다 ${ }^{3-5)}$. 방축가공은 스케일을 연화 또는 파괴하거 나 ${ }^{6,7)}$ 스케일을 피복하여 ${ }^{8,9)}$ 마찰계수의 방향이방 성효과(DFE)를 감소시키는 방법으로 실시한다. 습 식공정으로는 염소기체나 산화제를 주로 사용하 지만 반응속도가 매우 빨라서 불균일한 처리의 문 제점이 있으므로 반응속도가 상대적으로 느린 유기 염소계 화합물인 디클로로이소시아누릭산(DCCA :dichloroisocyanuric acid) ${ }^{10)}$ 이 널리 사용되어 왔다.
한편, 습식처리는 환경, 건조공정에 의한 에너지 비용 등의 문제를 발생 시키므로 이를 해결하기 위하여 건식에 의한 표면개질법이 연구되고 있다. 그 중에서 섬유 및 유기재료의 표면개질에 사용되 는 방전처리법은 ${ }^{11,12)}$ 주로 저온플라즈마 처리법으 로 방전에 의하여 전리된 기체중에는 고속으로 운 동하는 전자, 전리된 이온, 자외선, 라디칼, 여기분 자 등이 혼재된 전기적인 중성상태로서 이들을 이 용해서 섬유 및 고분자를 공격하면 라디칼에 의하 여 작용기도입과 표면이 깎이는 에칭(etching)이나 표면가교가 일어나며 가스의 종류에 따라서는 플 라즈마 중합이 일어나 시료표면의 물리적 화학적 성질이 변하게 된다.

저온플라즈마 ${ }^{13,14)}$ 를 폴리에스테르 및 각종의 섬 유에 이용하면 섬유표면의 에칭으로 염색물의 심 색효과가 얻어진다. 산소가스를 사용할 경우 표면 이 산소에 의하여 산화되어 한층 더 극성이 강해 지기 때문에 날염시 습윤 특성이 증가하며 코팅시 접착강도가 향상되고 친수성이 부여되는 등의

${ }^{\dagger}$ Corresponding author. Tel.: +82-55-350-5387; Fax.: +82-55-350-5389; e-mail: hlb@pusan.ac.kr 
기능성 가공에 사용되고 있다. 한편, 양모섬유에 저온플라즈마를 처리하면 ${ }^{15)}$ 습윤성이 증가하고 방 축성과 동시에 염색성이 향상된다고 알려져 있 다. 저온플라즈마 처리된 양모는 섬유의 손상도 거의 없고 기계적 성질의 변화를 일으키지 않으 면서 염료의 흡착율과 염색욕의 흡진율을 향상시 키므로 염색시간의 단축과 저온염색을 가능하게 한다. 미처리 양모와 동욕에서 염색할 경우 색상 차에 의한 차등염색효과(differential dyeing effect), 양모의 모선(tip)과 모근(root)부분의 염료의 흡수 ${ }^{1}{ }^{16)}$ 를 균일하게 하는 등의 실용적으로 많은 장 점이 기대된다.

본 연구에서는 양모섬유에 산소가스에 의한 저 온플라즈마 처리와 DCCA 처리한 양모직물의 염 료의 흡착성, 염색속도, 염색전이온도, 염료의 탈 착속도 등의 염색성의 변화를 미처리 직물과 비교 검토하였다.

\section{2. 실 험}

\section{1 시료 및 시약}

양모직물은 $2 / 36$ 번수의 경사밀도 124 본 $/ 5 \mathrm{~cm}$ 와 위사밀도 108 본 $/ 5 \mathrm{~cm}$ 이며 직물의 중량은 $294 \mathrm{~g} / \mathrm{m}^{2}$, 2/2능직의 백포 생지직물을 암모니아수와 음이온 계면활성제로서 세융하고, 연속탕신기에서 예비 셋팅한 후 건조한 백포직물을 시료로 사용하였다. 방축가공용으로 처리한 시약은 디클로로이소시아 누르산 소다 (DCCA: sodium dichloroisocyanuric acid) 로서 Aldrich사의 특급시약을, 초산 및 초산나트륨, 제4붕산나트륨, 피리딘, 무수황산나트륨, 아황산수 소나트륨 등은 시약급을 사용하였다.

2.2 플라즈마처리

저온플라즈마 처리장치는 원통형의 내부지름이 $220 \mathrm{~mm}$ 인 Horizental Type의 LP system, KR/WAP000TS (Wool Tec, Korea)의 평행 평판전극의 라디 오파 방전으로 $13.56 \mathrm{MHz}$ 를 사용하였으며 최대전력 은 $1600 \mathrm{~W}$ 이다. 방전 가스는 산소를 사용하고 시료 와 전극간 거리는 $75 \mathrm{~mm}$ 이며 진공도는 0.5 torr로 일 정하게 유지하고, 출력, 시간 등의 조건을 변화시키 면서 처리하였다. 플라즈마 처리한 시료는 $70^{\circ} \mathrm{C}$ 에 서 10 분간 수세한 후 염색시료로 사용하였다.

\subsection{DCCA 처리}

$\mathrm{DCCA}$ 처리는 습식 완료한 백포상태의 양모직물
을 적외선 가열식 로타리염색기(Mathis LABOMAT TYPE BFA-12, Switzland)에서 액비 1:50으로 조정 한 증류수에 비이온 계면활성제 $0.2 \%$, 무수황산나 트륨 $10 \%$ 를 용해시킨 후 희석한 초산수용액으로 $\mathrm{pH} 4.5$ 로 조정하고 $20^{\circ} \mathrm{C}$ 에서 10 분간 처리한 후 $\mathrm{DCCA}$ 를 시료 무게의 5\%(owf) 투입하고 용해 후 초산수용액으로 $\mathrm{pH}$ 를 4.5 로 재조정하여 $45^{\circ} \mathrm{C}$ 로 승 온하면서 60 분간 처리하였다. 탈염소처리는 동욕에 서 아황산수소나트륨 $2 \mathrm{~g} / 1$ 을 첨가하고 $50^{\circ} \mathrm{C}$ 에서 10 분간 처리 후 온수 및 냉수로 수세하였다.

\section{4 표면관찰}

산소가스를 사용하여 저온플라즈마 처리한 양모 섬유 및 5\%(owf) DCCA로서 방축 처리한 양모섬유 들의 표면 변화를 관찰하기 위하여 주사전자현미경 (SEM, HITACH S3500N, Japan)을 $20 \mathrm{KV}$ 의 가속전압 을 이용하여 측정하였다.

\section{5 염색 및 염착량}

염색은 플라즈마처리, DCCA처리 및 미처리의 시 료직물을 절단하여 일정량으로 평량하여 실온의 증류수에 담구고 탈수한 후 초산과 초산나트륨으 로 제조한 pH 5.5 완충용액의 욕비 1:300의 염욕에 서 Fig. 1에 나타낸 바와 같은 구조를 가진 밀링형 산성염료, Kayanol Milling Cyanine 5R (C.I. Acid Blue 113)을 소정의 염료농도, 염색온도, 염색시 간으로 적외선 가열식 로타리 염색기에서 염색 하였다. 염착량의 측정은 염색한 시료의 일정 량을 $25 \%$ 피리딘 수용액을 사용하여 $70^{\circ} \mathrm{C}$ 에서 염료를 추출한 후 분광광도계(OPTIZEN 3220UV, MECASYS, Korea)를 사용하여 최대흡수파장 $(\lambda \max$ $596 \mathrm{~nm}$ )에서 흡광도를 측정하고 미리 작성한 검량 선으로부터 계산하여 구하였다.

\section{C.I. Acid blue 113}

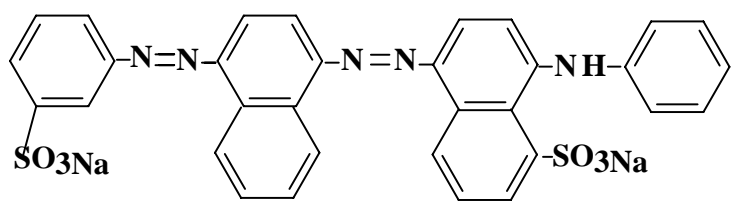

Fig. 1. Chemical structure of dye used in this study.

2.6 염료의 탈착속도

염료의 탈착율은 $4 \times 10^{-4} \mathrm{~mol} / \mathrm{L}$ 농도로 $80^{\circ} \mathrm{C}$ 에서 2 시간 염색한 각각의 직물시료를 분해하고 일정량으 
로 평량하여 시험관에 넣고 욕비 1:300의 $0.05 \mathrm{~mol} / \mathrm{L}$ 의 4 붕산나트륨 수용액 $(\mathrm{pH}=9.4)$ 을 첨가하여 진탕기 의 온도를 $70^{\circ} \mathrm{C}$ 로 하여 일정한 시간 간격으로 용액 을 채취하여 분광광도계로 흡광도를 측정하고 더 이상의 흡광도가 변하지 않는 값을 100 으로 하여 각 시간의 제곱근에 해당하는 추출액의 농도를 흡광도 로서 염료의 탈착율을 측정하였다.

\section{7 일광견뢰도, 강신도 및 구김회복성}

일광견뢰도는 크세논아크광에 의한 KSK ISO 105-B02법에 의하여 20시간 광퇴색한 후 표준청색 염포를 기준으로 등급을 판정하였다.

인장강신도는 KS K 0520 그래브법으로 하여 Instrong (Series IV Automated Materials Testing System)에서 Crossheah Speed 300mm/min, Load Range 5KN으로 측정하였고 상대습도 $55 \%$, 온도 $22^{\circ} \mathrm{C}$ 조건에서 경 사방향의 강도와 신도를 측정하였다.

구김회복성은 AATCC Test Method 66-1978에 의 한 Wrinkle Recovery Tester를 사용하여 Recovery Angle을 측정하였다.

\section{3. 결과 및 고찰}

\section{1 염색속도}

양모의 표면은 많은 양의 시스틴가교와 지방산 으로 구성된 큐티클층으로 형성되어 있으므로 소 수성을 나타낸다. 염소와 알칼리처리 등으로 큐티 클에 손상을 일으키면 친수성으로 변화한다. 건식 의 방법으로 저온플라즈마를 처리하면 스케일의 손상을 거의 발생시키지 않고도 섬유의 표면을 개 질할 수 있으므로 많은 연구가 되어왔다. Fig.3은 산소가스로서 0.5 torr의 진공도와 가스유량을 일정 하게 조정하고 방전출력과 처리시간을 변화시킨 $100 \mathrm{w} / 3$ 분처리, $200 \mathrm{w} / 5$ 분처리, $300 \mathrm{w} / 10$ 분처리와 $5 \%$ (owf) DCCA처리 및 미처리 양모직물의 시료를 밀 링형 산성염료인 Kayanol Milling Cyanine 5R (C.I. Acid Blue 113)으로 욕비 1:300, 염료의 농도 $4 X$ $10^{-4} \mathrm{~mol} / 1$, 염색온도 $60^{\circ} \mathrm{C}$ 로 염색한 각 시료의 염색 속도곡선을 나타내었다. DCCA 처리한 시료는 염 색초기에 미처리에 비하여 염착속도가 매우 빠르 며 염착량도 크게 증가하였고, 플라즈마 처리시료 는 출력과 처리시간이 증가할수록 염착량이 증가 하였다. 일반적으로 개질화한 양모섬유를 분자량 이 적은 균염성 산성염료로 염색할 때 염색초기에 는 염착량이 크게 증가하여 염색속도의 차이를 나
타내지만 일정시간 경과 후 평형염색에서는 거의 동일한 염착량을 보이는 경향을 나타내는 것으로 알 려져 있다. 염색초기 염착량의 증가는 에피큐티클의 발수성이 약품에 의해 손상되거나 플라즈마 처리의 경우 에칭이나 작용기의 도입으로 인하여 친수성으 로 변화되어 염료입자가 섬유내부에 쉽게 침투 확산 할 수 있기 때문이며 미처리 시료에서도 일정시간 이후에는 스케일층의 팽윤에 의해 장벽의 효과가 감소되어 적은 분자량의 염료는 섬유 내 확산이 쉽게 되어 평형염색에서는 거의 동일한 염착량을 나타낸다. 한편, 분자량이 크고 벌크한 구조의 밀링 형 염료의 경우에도 개질한 양모에서는 같은 이유 로 염색초기에는 염착량이 증가하며 평형염색에 도 달하는 시간도 단축되지만 평형염색에서는 미처리 양모에 비하여 매우 큰 염착량의 차이를 나타낸다.

양모섬유에 대한 산성염료의 염색에 대하여 Leeder ${ }^{17)}$ 등의 주장에 의하면 양모섬유에서 염료 의 침투는 에피큐티클 표면으로부터 세포내로 확 산이 일어나는 것이 아니고 스케일 사이의 세포간 접합물질(CMC: cell membrane complex)을 통하여 염착이 일어난다고 하였다. 또한, Wakida ${ }^{18)}$ 등에 의하면 플라즈마 처리에 따른 양모섬유의 경우 스 케일 사이에 있는 세포막 접착층 $(\mathrm{CMC})$ 의 구조이 완에 의하여 염색성이 향상된다고 하였다. 동일한 시료의 수불용성의 분산염료에서는 미처리와 차 이가 없는 것으로부터 양모의 $\mathrm{CMC}$ 의 구조이완은 수용성 염료에서만 적용된다고 하였다. 수용성 염 료는 스케일을 통하여 염료가 흡수되지만 분산염 료의 경우 스케일 사이로 염료가 확산되므로 구조 이완과 관련하여 염착량의 차이가 없게 된다고 주 장하였다. 이와 같이 산성염료의 양모섬유에 대한 염색의 두 가지 주장은 염료가 스케일 사이의 접 합물질을 통하여 침투한다고 주장하는 이론과 스 케일 사이에 있는 세포막 접착층 $(\mathrm{CMC})$ 의 구조이 완에 의해서 염료가 쉽게 침투할 수 있다고 하는 주장이다. 플라즈마 처리한 시료는 염색초기에는 염착량의 증가가 매우 적다가 일정시간 후에는 크 게 증가하는 것은 에칭과 산소원자의 작용으로 작 용기의 도입, 스케일의 구조이완 및 섬유표면의 친 수화 효과가 염착량의 증가에 영향을 미쳤다고 생 각되며, Fig. 2에서와 같이 DCCA를 처리한 경우에 는 스케일의 손상에 의하여 처음부터 염색의 장벽 효과가 제거되었으므로 염색초기부터 염착량이 크 게 증가하고, 염료의 탈착속도시험에서도 높은 탈 착율을 나타내는 것으로 생각된다. 


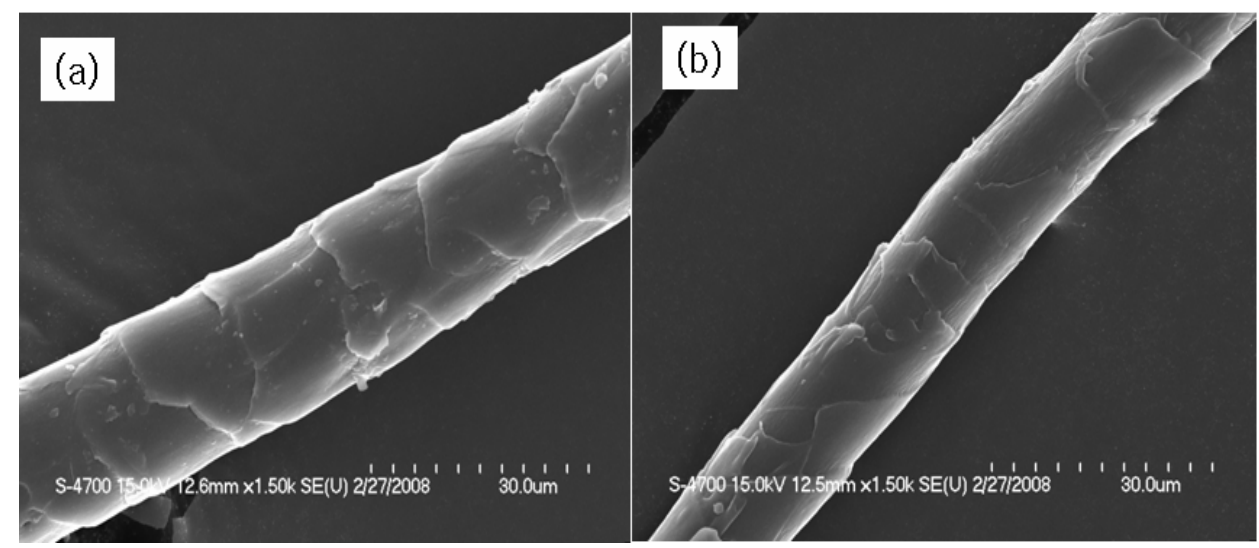

(a) 300w/10min plasma treated wool

(b) $5 \%$ (owf) DCCA treated wool

Fig. 2. SEM image from the surface of plasma treated wool and DCCA treated wool.

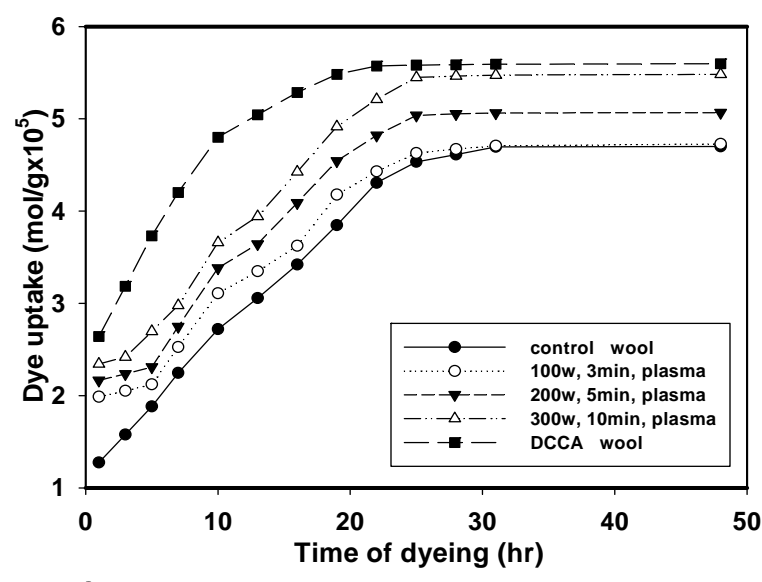

Fig. 3. Relationship between time of dyeing and dye exhaustion of wool at $60^{\circ} \mathrm{C}$.

\section{2 염색전이온도}

합성섬유의 염색이 시작되는 온도와 섬유의 유 리전이온도가 일치하는 것은 고분자쇄의 분절 이 동성으로 인하여 섬유내로 염료의 확산이 가능하 다는 이론을 충분히 지원하고 있다. 폴리에스테르 와 아크릴섬유에서 $70-80^{\circ} \mathrm{C}$ 에 도달할 때 까지 섬 유내로 염료의 확산이 거의 일어나지 않지만 그 이 후에는 확산속도가 급격히 증가하므로 염색전이온 도라는 용어로 표현되었고 물리적인 방법으로 측 정한 유리전이온도와의 차이가 크지 않다. 따라서 폴리에스테르 섬유의 염색에서 열처리, 케리아, 유 기용매처리는 섬유의 내부구조를 변화시키고 염색의 전이온도에 영향을 미친다. 개질한 양모섬유에서도 구조변화의 결과로서 염색온도에 급격한 흡착량의 변화를 나타내는 염색전이온도를 확인하고자 각 시료를 동일한 조건으로 염색하고 염료의 흡착량 과 염색온도사이의 관계를 Fig. 4에 나타내었다.

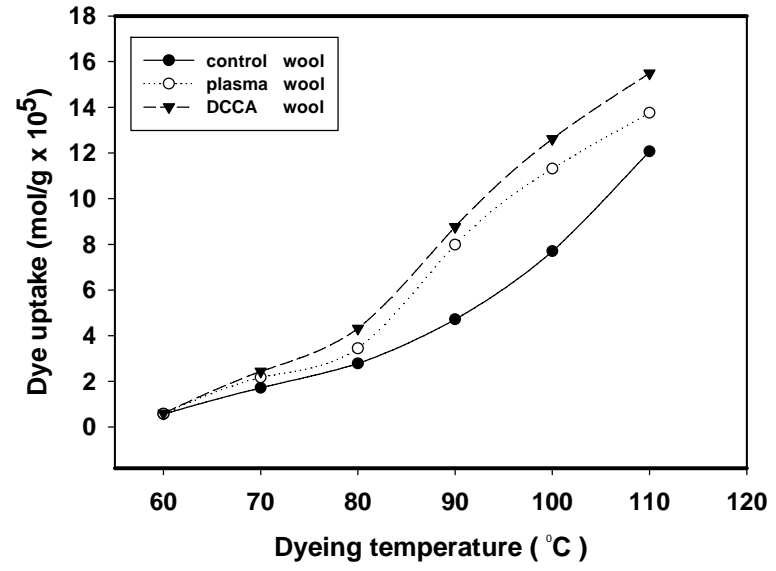

Fig. 4. Relationship between dye uptake and dyeing temperature.

각 온도에서 10 분간 염 색한 시료의 염착량을 측정한 것으로 DCCA 처리한 시료와 $300 \mathrm{w} / 10$ 분 간 플라즈마 처리한 시료가 미처리 시료에 비하 여 높은 염착량을 나타내었다. 10 분의 짧은 염색 시간의 조건에서 염 색온도 $70^{\circ} \mathrm{C}$ 까지는 모든 시료 에서 염착량의 차이가 적지만 $80^{\circ} \mathrm{C}$ 이상에서는 개 질한 시료의 염착량이 급격하게 증가하였다. 개질 한 양모는 플라즈마 처리에 의한 스케일의 구조이 완과 DCCA 처리에 의한 스케일의 손상으로 인하 여 염료의 침투가 쉽게 될 수 있는 물리적인 스케 일의 구조변화와 염색온도의 상승에 따른 염료입 자의 운동성 증가로 염착량이 크게 높아졌다고 생 각된다. Fig. 4에는 DCCA와 플라즈마 처리로서 개질한 시료는 $85^{\circ} \mathrm{C}$ 부근에서 급격한 염착량의 증가로 인한 그래프의 $\mathrm{S}$ 자모양의 변형(sigmoid)을 보이는 염색전이온도를, 또한 미처리 시료에서는 $105^{\circ} \mathrm{C}$ 부근에서 $\mathrm{S}$ 자모양의 변형인 염색전이온도 를 나타내었다. 


\section{3 포화염착량}

DCCA 처리한 시료와 $300 \mathrm{w} / 10$ 분간 산소플라즈 마 처리한 시료 및 미처리 시료의 밀링형 산성염 료에 대하여 염색 후 구한 $[\mathrm{D}]_{\mathrm{f}}$ 및 $[\mathrm{D}]_{\mathrm{s}}$ 의 값으로부 터 그 역수를 플롯한 결과를 Fig. 5에 나타내었다. 모든 시료에서 $1 /[\mathrm{D}]_{\mathrm{f}}$ 와 $1 /[\mathrm{D}]_{\mathrm{s}}$ 는 직선관계를 나타 내고 있으므로 양모섬유에 대한 산성염료의 흡착 은 전형적인 Langmuir형의 흡착을 확인할 수 있었 다. Langmuir 흡착 등온식에서 플롯의 절편의 역수 값으로부터 해당 염료에 대한 포화 염착량을 구한 결과를 Table 1에 나타내었다. Langmuir의 흡착 등 온식은 염료의 흡착이 섬유 내 특정좌석에만 일어 나며 한 염료분자가 좌석을 차지하면 그 좌석은 포화되고 더 이상 흡착할 능력이 없다고 가정한 것이다. 미처리 시료에서 포화염착량은 섬유고분 자내의 작용기의 종류나 염료의 침투 용이성이 성 장과정에서 결정되는 고유의 물리적 구조에 관련 된 염색특성에서 나타나는 포화 값으로 생각된다. 플라즈마와 DCCA로 개질한 시료는 염색 이전의 공정에서 스케일의 손상, 에칭과 작용기도입, 스케 일의 구조이완, 섬유표면의 친수화 등의 물리적 또는 화학적 구조의 변화가 결과적으로 섬유내부 의 염착좌석을 증가시켜 염색속도와 포화염착량 의 변동을 일어킨 것으로 생각된다.

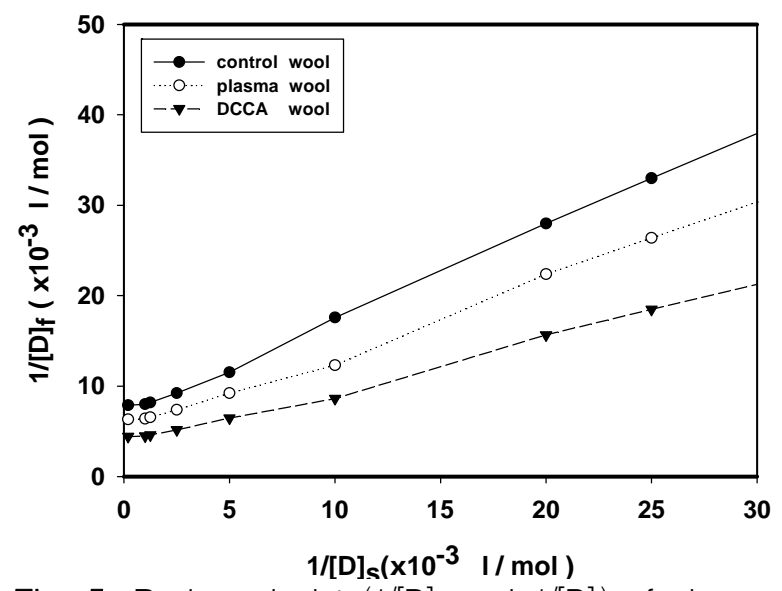

Fig. 5. Reciprocal plot $\left(1 /[\mathrm{D}]_{\mathrm{s}}\right.$ and $\left.1 /[\mathrm{D}]_{\mathrm{f}}\right)$ of plasma treated wool, DCCA treated wool and control wool.

Table 1. Saturation dye exhaustion of wool fibers treated with plasma and DCCA

\begin{tabular}{cc}
\hline Specimen & $\begin{array}{c}\text { Saturation dye exhaustion } \\
\left(\mathrm{mol} / \mathrm{g} \times 10^{4}\right)\end{array}$ \\
\hline Control wool & 1.26 \\
300w/10min plasma & 1.58 \\
$5 \%$ (owf) DCCA & 1.76 \\
\hline
\end{tabular}

\section{4 탈착속도}

표면 개질한 양모섬유를 밀링형 산성염료로 염 색할 경우 미처리 시료에 비하여 염색속도가 빠 르고 포화염착량이 증가하는 이유는 관능성기의 도입, 양모표면의 친수화, 스케일의 파괴, 에칭 등 에 의한 화학적 조성의 변화와 세포막 접합물질 $(\mathrm{CMC})$ 의 구조이완 등 여러 가지 복합적인 작용 에 의하여 변화된 결과로 나타나지만 염료의 종 류에 따라 각각 다른 방식으로 염색기구가 달라 진다. Fig. 6은 $4 \times 10^{-4} \mathrm{~mol} / 1$ 의 염료농도로 $90^{\circ} \mathrm{C}$ 에 서 120 분간 염색한 각 시료를 $0.05 \mathrm{~mol} / 1$ 의 4 붕산 나트륨 수용액 $\left(\mathrm{pH}\right.$ 9.4)중에서 $70^{\circ} \mathrm{C}$, 욕비 $1: 300$ 으 로 하여 염료를 탈착시키면서 일정한 시간 간격 으로 염액을 채취한 후 흡광도를 측정하여 탈착 량을 계산하고 탈착시간의 제곱근에 대한 탈착율 을 나타낸 것이다. 탈착율은 추출에 의하여 더 이 상의 흡광도 변화가 없는 흡광도의 값을 기준으 로 탈착시간의 제곱근의 흡광도를 백분율로 나타 낸 것이다. 모든 시료에서 탈착의 초기에는 직선 관계를 나타내고 있다. 탈착율과 탈착시간의 제 곱근과의 관계는 흡착율과 흡착시간의 제곱근과 의 관계와 마찬가지로 탈착에 동반되는 확산계수 에 대응하는 개념으로 생각할 수 있다. 따라서 직 선의 기울기는 DCCA 처리한 시료가 가장 크고 플라즈마 처리한 시료도 미처리에 비하여 상당히 크게 나타났다. DCCA 처리에 의하여 양모 스케 일의 탈락으로 염료의 흡착이 쉽게 일어나는 것 에 비례하여 염료의 탈착 또한 쉽게 일어나므로 세탁 및 일광견뢰도 측면에서 단점으로 작용할 것으로 생각된다.

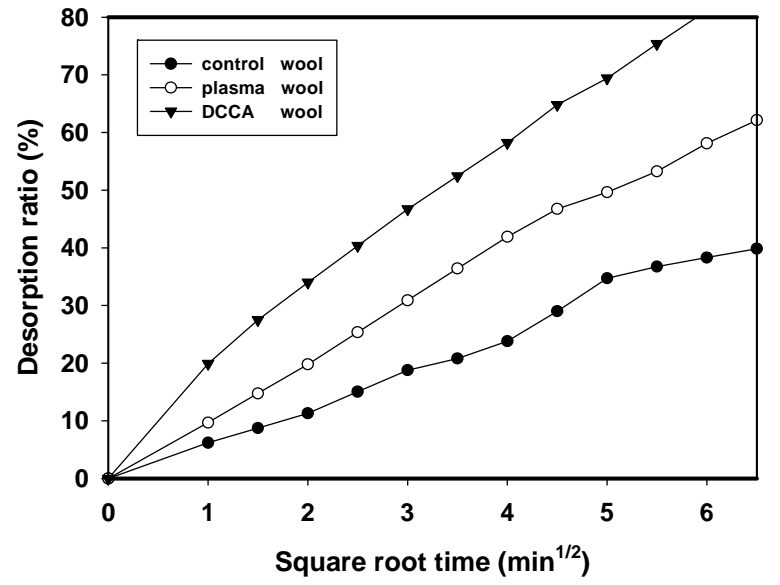

Fig. 6. Relation between dye desorption ratio and square root of time at $70^{\circ} \mathrm{C}$. 


\section{5 물성변화}

Table 2 에는 $4 \times 10^{-4} \mathrm{~mol} / 1$ 의 염료농도로 $90^{\circ} \mathrm{C}$ 에 서 120 분간 염색한 각 시료의 물성을 나타낸 것이 다. 크세논 아크등에 의한 20시간 조광한 후 표준 청색염포와 비교하여 나타낸 일광 견뢰도는 미처 리 및 플라즈마 처리 시료에서는 4 급으로 나타났 고 DCCA 처리한 시료는 3 급으로 나타났다. DCCA 처리한 시료는 스케일의 손상으로 염욕이나 수용 액에서 염료의 흡착과 탈착이 쉽게 일어날 뿐만 아니라 표면에 흡착된 과잉의 염료는 광에 의한 퇴색 또한 쉽게 일어나지만 플라즈마 처리한 시료 는 상대적으로 양호한 내광견뢰성을 나타내었다. 세탁견뢰도는 염색된 시료로부터 세정욕으로의 탈착속도 및 탈착량에 크게 관계되므로 DCCA 처 리한 시료에서 염색속도가 증가하는 것은 염료의 확산속도가 증가하는 것으로 저온염색 혹은 농색 의 염색에서는 개선효과로 작용하지만 역으로 세 탁이나 일광에 의한 견뢰도 측면에서 적정한 수준 의 제어가 필요할 것으로 생각된다. 한편, 산소 플 라즈마 처리에 의한 양모섬유의 표면개질은 섬유 표면의 극히 얕은 층에서 스케일의 손상은 거의 없고 주로 구조이완이 일어나므로 염색견뢰도의 문제는 없을 것으로 생각된다. 경사방향으로 측정 한 인장 강신도는 미처리 시료의 경우 강도는 $549(\mathrm{~N})$, 신도는 $46 \%$ 이며 DCCA 처리한 시료에서 는 강도는 $445(\mathrm{~N})$, 신도는 $48.1 \%$ 이고 $300 \mathrm{w} / 10$ 분 플라즈마 처리한 시료는 강도는 663(N), 신도는 $49.5 \%$ 로 미처리 시료 보다 오히려 증가하는 경향 을 나타내었다. 플라즈마 처리한 시료는 촉감이 딱딱하고 상대적으로 구김회복성의 감소를 초래 하였다.

Table 2. The mechanical properties of control wool fabric, DCCA treated wool fabric, and plasma treated wool fabric

\begin{tabular}{cccc}
\hline Item & Control & DCCA & Plasma \\
\hline $\begin{array}{c}\text { Light color fastness } \\
\text { (grade) }\end{array}$ & 4 & 3 & 4 \\
$\begin{array}{c}\text { Tensile Strength } \\
(\mathrm{N})\end{array}$ & 549 & 445 & 663 \\
$\begin{array}{c}\text { Elongation } \\
(\%)\end{array}$ & 46 & 48.1 & 49.5 \\
$\begin{array}{c}\text { Crease Recovery } \\
(\mathrm{wp} / \text { wf degree) }\end{array}$ & $140 / 150$ & $140 / 130$ & $120 / 110$ \\
\hline
\end{tabular}

\section{4. 결 론}

모직물의 형태안정성과 염색성을 개선할 목적 으로 습식법으로는 염소계 유기화합물인 DCCA

를 5\%(owf)농도로 처리하고, 건식법으로는 산소 가스를 사용하여 진공도 0.5 torr에서 $300 \mathrm{w} / 10$ 분 간 처리한 시료와 미처리 시료를 밀링형 산성염료 (C.I. Acid Blue 113)로서 염색하고 염색성의 차이 를 비교 검토한 결과 다음과 같은 결론을 얻었다. 1. 플라즈마 처리한 시료는 방전출력 및 처리시간 에 비례하여 염색속도 및 포화염착량의 증가를 나타내었고, DCCA 처리한 시료는 염색초기에 매우 높은 염착량과 평형염색에서 염착량도 크 게 증가하였다.

2. 염색온도에 따른 염색거동은 플라즈마 처리와 $\mathrm{DCCA}$ 처리한 시료는 $95^{\circ} \mathrm{C}$ 에서, 미처리 시료에 서는 $105^{\circ} \mathrm{C}$ 에서 급격한 염착량의 증가를 나타내 는 염색전이온도로 생각된다. 곡선의 변형은 합 성섬유의 유리전이온도에서 염색기구와 동일한 개념으로 표면개질한 양모섬유에 대하여 염색 전이온도의 변화를 확인할 수 있었다.

3. 염욕중의 염료의농도 $\left([\mathrm{D}]_{\mathrm{s}}\right)$ 와 섬유에 흡착된 섬 유의 염료농도 $\left([\mathrm{D}]_{\mathrm{f}}\right.$ 를 구하고 그 역수를 플롯한 것으로부터 직선관계를 얻은 개질한 양모섬유 의 흡착거동 또한 Langmuir형의 흡착식을 나타 내며 절편의 기울기로부터 구한 포화염착량은 $300 \mathrm{w} / 10$ 분 플라즈마 처리한 시료는 미처리 시료 에 비하여 $25 \%, \mathrm{DCCA}$ 처리한 시료는 약 $40 \%$ 정도 증가하였다.

4. 염색한 시료의 붕산염에 의한 탈착율은 탈착시 간의 제곱근에 대하여 플롯하면 짧은 시간 범위 에서는 직선의 관계가 이루어지고, DCCA 처리한 시료의 기울기가 가장 큰것으로부터 세탁이나 일 광의 견뢰도가 우려되므로 적절한 후가공의 보완 이 요구된다.

\section{참고문헌}

1. W. E. Morton and J. W. S. Hearle, "Physical Properties of Textile Fibres," university of Manchester, Heinemann, U. K., pp.159-176, 1975.

2. P. G. Tortora and B. J. Collier, "Understanding Textiles", 5th ed., Prentice-Hall, inc., U. K., pp.93124, 1997.

3. J. A. Maclaren and B. milligan, "wool science", Science Press, Australia, pp.77-88, 1981. 
4. M. Bona, "Textile Quality": physical methods of product and process control, Texilia, Istituto perla, Italy, pp.88-120, 1994.

5. M. L. Joseph, "Introductory Textile Science", California State University, U.S.A., pp.50-67, 1980.

6. I. W. Stapleton, Shrink-Resist Efficiency Enhancement of two Polymers on Wool by polyamine Pretreatments, Text. Res. J., 53(7), 445-451(1983).

7. J. R. Cook and D. E. Rivett, Amine Pretreatments for Enhancing the Polymer Shrinkproofing of Wool, Text. Res. J., 51(9), 596-600(1981).

8. G. B. Guise and G. N. Freeland, Treatment of Wool Fabrics with Mixtures of Fluorchemicals and Shrink-Resist Polymers, Text. Res. J., 52(3), 182185(1982).

9. A. Bereck and B. Kamien, Shrink-Resist Treatments of Wool Fabrics with Water-Soluble Acrylic Copolymers, Text. Res. J., 49(5), 247-249 (1979).

10. T. Shaw, M. A. White, "Handbook of Fiber Science and Technology": Vol. II, Chemical Processing of Fibers and Fabrics, Functional Finishes (M. Lewin and S. B. Sello eds) New York: Part B, Marcel Dekker, Chapter 5, pp.346367, 1984.

11. I. M. Zuchairah, M. T. Pailthore and S. K. David, Effect of Glow Discharge-plymer Treatments on the Shrinkage Behavoir and Physical Properties of Wool Fabric, Text. Res. J., 67(1), 69-74(1997).
12. A. E. Pavlath and K. S. Lee, Effect of the After glow on the Felting Shrinkage of Wool, Text. Res. J., 45(2), 742-745(1975).

13. C. W. Kan, K. Chan, C. W. M, Yuen, and M. H. Miao, Low Temperature Plasma on Wool Substrates: The Effect of the Nature of the Gas, Text. Res. J., 69(6), 407-416(1999).

14. A. M. Sarmadi, T. H. Ying, and F. Denes, Surface Modification of Polypropylene Fabrics by Acrylonitrile Cold Plasma, Text. Res. J., 63(2), 697705(1993).

15. J. Ryu, T. Wakida, and T. Takagishi, Effect of Corona Discharge on the Surface of Wool and Its Application to printing, Text. Res. J., 61(10), 596601(1991).

16. M. K. Rigby, J. G. Robinson and H. K. Mitchell, The Effect on Dyeing and Bleaching of Tip-to-root Differences in Wool Fibres, J. Text. Inst., 73(2), 94-96(1982).

17. J. D. Leeder, J. A. Rippon and D. E. Rivett, Proceedings of "The 7th Wool Text. Res. Conf.", 4, 312, tokyo, 1985.

18. T. Wakida, M. C. Lee, P. K. Pak and J. Chen, Dyeing Transition Temperature of Wool treated with Low Temperature Plasma, Liquid Ammonia and High-Pressure Steam in dyeing with Acid and Disperse Dyes, J. Appl. Polyme. Sci., 80, 10581062(2001). 